ELORE (ISSN 1456-3010), vol. 19 - 2/2012.

Julkaisija: Suomen Kansantietouden Tutkijain Seura ry.

[http://www.elore.fi/arkisto/2_12/mahlamaki.pdf]

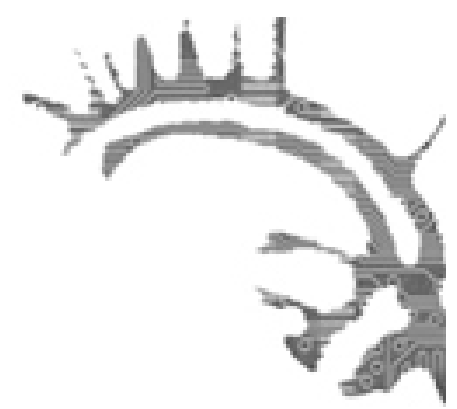

KirJa-ARViO

\title{
ASIALLISESTI VANHOILLISLESTADIOLAISUUDEN ASIATTOMUUKSISTA
}

LINJAKUMPU, AINI 2012: Haavoittunut yhteisö. Hoitokokoukset vanhoillislestadiolaisuudessa. Tampere: Vastapaino. 270 sivua.

\section{$\underline{\text { Tiina Mahlamäki }}$}

Vanhoillislestadiolaisen liikkeen sisäiset ongelmat ja liikkeessä tapahtuneet väärinkäytökset ovat viime vuosina nousseet julkisen keskustelun ja hämmästelyn kohteiksi. Kissan ovat nostaneet pöydälle erityisesti liikkeen sisällä syntyneet ja kasvaneet naiset, jotka kokemistaan ja havaitsemistaan epäkohdista huolimatta edelleenkin kokevat yhteisön omaksi henkiseksi kodikseen. Heillä on ollut rohkeutta nostaa esiin kipeitä, arkaluontoisia ja vaiettuja seikkoja liikkeen sisällä, koska he ovat nähneet sen tärkeäksi juuri liikkeen itsensä kannalta, jotta liike voisi kehittyä eteenpäin. Erityisesti keskustelua ovat herättäneet lapsien seksuaalinen hyväksikäyttö, ehkäisykielto sekä naispappeus.

Politiikantutkija Aini Linjakumpu Lapin yliopistosta on julkaissut tärkeän tutkimuksen vanhoillislestadiolaisuuden yhdestä kipupisteestä: 1970-luvun lopun hoitokokousajasta. Monet liikkeen jäsenet joutuivat tuolloin ankarien toimenpiteiden kohteiksi, kun heitä vaadittiin julkisissa tilaisuuksissa tunnustamaan syntejään ja anomaan anteeksiantoa. Osa hoidettavista joutui myös erotetuksi liikkeestä vastoin omaa tahtoaan. Vaikka tutkimuksen painopiste on yli 30 vuoden takaisissa tapahtumissa, se on silti erittäin ajankohtainen. 1970-luvun tapahtumat haavoittivat Linjakummun mukaan sekä liikettä kollektiivisesti että lukuisia yksittäisiä liikkeen jäseniä. Siksi hoitokokousten syitä, 
tapahtumakulkuja ja seurauksia on tärkeä valottaa. Lestadiolaisuus elää murrosaikaa, ja nähdäkseni myös Linjakummun tarkoituksena on tarjota välineitä liikkeen eheyttämiseen ja kehittämiseen nyky-yhteiskuntaan soveltuvammaksi.

Linjakummun tutkimuksen keskeiseksi teoreettiseksi kysymykseksi nousee, minkälaista vallankäyttöä hoitokokoukset edustavat. Politiikan tutkijana hän on erityisen herkkä vallankäytön eri muotojen tarkastelussa. Toinen keskeinen käsite on emootio ja kysymys siitä, miten hoitokokoukset on koettu ja minkälaisia tunteita hoitokokoukset ovat aiheuttaneet niihin osallistuneissa ihmisissä ja heidän lähipiirissään. Hoitokokousajan tapahtumien Linjakumpu näkee aiheuttaneen yhteisössä kollektiivisen trauman ja tehneen yhteisöstä ja sen jäsenistä haavoittuneita. Tutkimuksen lopussa hän tuo esiin tapoja, joilla tätä traumaa on pyritty yhtäältä piilottelemaan ja toisaalta hoitamaan sekä pohtii sitä, miten yhteisön tulisi traumaa käsitellä.

Tutkimus on moniaineistoinen. Keskeinen aineisto muodostuu Linjakummun lähettämän tutkimuspyynnön tuottamista haastattelu- ja sähköpostiaineistoista. Toinen suuri aineistoryhmä koostuu internetkeskusteluista ja blogikirjoituksista. Lisäksi Linjakumpu käyttää monipuolista sanomalehtiaineistoa, aikaisempaa tutkimuskirjallisuutta sekä liikkeen itsensä tuottamaa ja tutkimuksen käytettävissä olevaa materiaalia.

\section{KUKA SAA TUTKIA JA MITEN?}

Lestadiolaisuuden tutkimuksessa on selkeä aukkopaikka, sillä yhtäältä liikettä tutkineet ovat usein tulleet yhteisön sisältä ja toisaalta tutkimuksissa on pitkälti keskitytty historiallisiin ja opillisiin kysymyksiin sekä liikkeen perustajan Lars Levi Laestadiuksen henkilöön. Ongelmakohdat ovat jääneet pitkälti tutkimuksen ulottumattomiin, vaikka poikkeuksiakin on (ks. esim. Suolinna \& Sinikara 1986; Pyysiäinen 2005). Sisä-ulkopiiri-ongelma on yksi uskontotieteen ikuisuuskysymyksistä. Sisäpiiriläisellä on tietoa, jota ulkopuolisen on vaikea tavoittaa ja suora pääsy yhteisön sisälle. Yhteisön ulkopuolisen tutkijan tuottama tieto nähdään usein objektiivisempana tai neutraalimpana. Mutta ulkopuolisellakin tutkijalla on ennakkoasenteensa ja rajoitteensa. Keskeistä on reflektoida omaa asemaansa ja pohtia avoimesti sen vaikutusta tutkimusprosessiin. Neutraalia tietoa ei olekaan, vaan kaikki tieto on paikantunutta. Tässä tutkimuksessa ei varsinaisesti paikannuta suhteessa tutkittavaan liikkeeseen, mutta sitäkin selkeämmin reflektoidaan metodologisia kysymyksiä, aineiston validiteettia ja teoreettista viitekehystä.

Toinen uskonnollisten yhteisöjen tutkijoita askarruttava ongelma liittyy arkaluontoisten, negatiivisten tai leimaavien asioiden tutkimiseen. Tutkimuseettisiä kysymyksiä Linjakumpu pohtii ansiokkaasti ja huolehtii tarkasti informanttiensa anonymisoinnista. Kun uskonto nähdään yksityisasiana, kuten tämän päivän suomalaisessa yhteiskunnassa, ajatellaan, että uskonnolliset ongelmatkin ratkotaan perhepiirissä, kodissa, muiden katseilta piilossa. Toisaalta vanhoillislestadiolaisen liikkeen näkemys, jossa tehdään jyrkkä ero yhteisön ja muun yhteiskunnan välille, estää arkaluontoisten asioiden käsittelyn julkisuudessa. Siksi onkin ensiarvoisen tärkeää, että tutkija käyttää valtaansa nostaa esiin tärkeitä ja arkaluontoisia kysymyksiä. Linjakumpu ei käsillä olevassa teoksessa 
pyri leimaamaan tai syyttämään, vaan hän koettaa tuoda esille niitä syitä, jotka johtivat hoitokokousaaltoon sekä antaa äänen hoitokokouksiin osallistuneiden tunteille. Tosin itse hoitajien tunteet jäävät tämän tutkimuksen ulkopuolelle.

\section{MIKSI HOITOKOKOUKSIA JÄRJESTETTIIN?}

Linjakumpu löytää useita syitä sille, miksi vanhoillislestadiolaisuudessa 1960-1970-luvuilla vallitsi niin sanottu hoitokokousaika. Syyt olivat sekä yhteiskunnallisia, yhteisöllisiä, organisatorisia että teologisia. Intensiivinen hoitokokousaika oli reaktio muuttuneeseen yhteiskunnalliseen tilanteeseen, jossa perinteiset arvot tuntuivat kadonneen. Se aiheutui myös yhteisön yhtenäisyyden vaatimuksesta, sillä lestadiolaisuuden mukaan pelastus löytyy vain liikkeen sisältä, jolloin rajanveto meidän ja muiden välille nousee erittäin tärkeäksi. Linjakumpu nimittää vanhoillislestadiolaisuutta kiinnostavasti elämäntapauskonnollisuudeksi (s. 48). Se voi maallistuneessa nyky-Suomessa siltä näyttääkin, mutta suurin osa maailman uskontoperinteistä täyttää elämäntapauskonnollisuuden tunnusmerkit. Uskonto on jotain, joka kuuluu ja on läsnä koko elämässä, sen kaikissa valinnoissa. Uskonto ei suurelle osalle maailman ihmisistä ole yksityisasia, irrallaan muusta elämästä.

Hoitokokousajan syntyyn vaikuttivat niin liikkeen sisäiset kuin ulkoiset tekijät. Johtuen yhteiskunnallisista murroksista liikkeessä ryhdyttiin korostamaan lopunaikojen läheisyyttä. Myös toiseuttaminen oli vahvaa. Yhtäältä kriittisyys luterilaista kirkkoa kohtaan kasvoi (ulkoinen toiseus) ja toisaalta alettiin korostaa eriseuraisuutta (sisäinen toiseus). Eriseuraisuus nähtiin vaarallisena eli kyseessä on lahkotyyppinen ajattelutapa, jossa korostetaan ulkoisia uhkia, pyritään tiivistämään yhteisöä sisältäpäin sekä korostamaan oikein uskomista ja elämistä. Tämä johti siihen, että uskonsisarten ja -veljien ajattelua ja toimintaa ryhdyttiin vartioimaan entistäkin tiukemmin.

Teologisista syistä erityisesti kaksi opetusta nousee merkittäväksi hoitokokouksien taustalla: Kristuksen kirkkolaki sekä henkioppi. Vanhoillislestadiolaisen liikkeen jäsen joutui hoitokokouksen kohteeksi, hoidettavaksi jonkun yhteisön jäsenen "ilmiantaessa" hänet, toisin sanoin osoittaessaan huolestuneisuutensa tämän käyttäytymisestä tai uskon tilasta. Itse kokouksessa hoidettava ei voinut puolustautua, vain osoittaa katumusta. Kukaan muukaan ei voinut häntä puolustaa, sillä se olisi osoittanut synnillisen ajattelutavan tai toiminnan puolustamista. Katuminenkaan ei aina riittänyt, vaan henkilö saattoi joutua hoidettavaksi kerran toisensa jälkeen. Hoitokokouksen tuloksena oli katuminen tai parannuksenteko ja sitä seuraava anteeksianto. Hoidettava saatettiin myös sitoa synteihinsä eli eristää yhteisöstä, kunnes hän nöyrtyi parannukseen. Rankin lopputulos oli yhteisöstä erottaminen.

Henkioppi selittää sen, mistä syistä ihminen nähtiin hoidon tarpeessa olevaksi. Erilaiset asiat määrittyivät syntisiksi juuri henkiopin perusteella: joutuessaan väärän hengen vaikutusvallan alle ihmisen valtasi väärä henki, eriseuraisuus, mistä oli seurauksena väärin uskominen sekä väärät teot. Hoidettavaksi joutumiseen saattoivat johtaa monenlaiset "synnit", jotka liikkeen ulkopuolisille olivat osa arkista elämää. Syytökset saattoivat kui- 
tenkin olla usein epämääräisiä ja syytettyjen saattoi olla vaikea ymmärtää, mistä heitä syytettiin, mitä heidän tulisi katua. Linjakummun kuvaus ja informanttien kertomukset hoitokokouksista tuovat mieleen populaaritulkinnan inkvisition toiminnasta tai George Orwellin Vuonna 1984 -teoksen, jossa väärinajattelu on kiellettyä.

\section{MILTÄ HOITOKOKOUKSET TUNTUIVAT?}

Linjakumpu käsittelee tutkimuksessaan nimenomaan hoitokokousten ongelmallisia piirteitä, eikä sitä, miten jotkut saattoivat kokea ne myönteisinä ja uskoaan vahvistavina. Työkalukseen Linjakumpu ottaa emootion käsitteen. Vaikka tunteiden tutkimus käyttäen aineistona vuosikymmeniä myöhemmin kerättyä muistitietoa voi tuntua epärelevantilta, sitä se ei suinkaan ole. Tunteet ovat kokijoilleen tosia, vuosikymmenestä toiseen. Hoitokokoukset vaikuttivat paitsi itse hoidettaviin myös heidän läheisiinsä, sillä hoidettavien lapset joutuivat usein olemaan kokouksissa läsnä. Tämä laadulliseen näkökulmaan ja yksilön kokemuksiin ja tunteisiin painottuva luku on tutkimuksen koskettavin. Siinä kuvataan sitä, minkälaisina ihmiset kokivat hoitokokoukset, miten ne vaikuttivat heidän elämäänsä, miten he ovat kokemustaan työstäneet sekä myös sitä, miten vanhoillislestadiolainen liike voisi oppia menneisyydestään ja kehittyä parempaan suuntaan.

Itsen tai läheisen joutuminen hoidettavaksi saattoi aiheuttaa sen, että luottamus yhteisöön mureni, monilta katosi tunne oman elämänsä hallinnasta ja heidät valtasi epävarmuus oman uskonsa laadusta (oikein uskomisesta). Hoidettavaksi joutuminen saattoi aiheuttaa mielenterveysongelmia sekä monenlaista epävarmuutta, huolta, syyllisyydentuntoja ja elämänhallinnan katoamista. Katkeruutta ja vihaa löytyy erityisesti niiden kohdalla, jotka erotettiin liikkeestä vastoin heidän omaa tahtoaan. Mielenkiintoisella tavalla nämä monenlaiset tunteet keskustelevat sen kanssa, miten uskontotieteilijä Seija Ronimus väitöskirjassaan Vartiossa maailmaa vastaan (2011) kuvaa Jehovan todistajista poiskääntyneiden kokemuksia. Vahvasta yhteisöstä, elämäntapauskonnosta, eroaminen tai erottaminen on erittäin traumaattinen kokemus; sen myötä ihminen menettää paitsi ystävyys- ja sukulaissuhteensa myös tuonpuoleisuuden ja pelastuksen, sillä yhteisön ulkopuolella oleville ei ole tarjolla muuta kuin kadotus.

\section{Miten haAvoitTUnUt Yhteisö Voi PARANTUA?}

Linjakumpu näkee hoitokokousajan haavoittaneen merkittävällä tavalla vanhoillislestadiolaista liikettä. Hänen mukaansa liikkeellä ja erityisesti sen johdolla on kollektiivinen vastuu tapahtuneesta. Liikkeessä kun on pyritty näkemään hoitokokousten ongelmat yksittäisten ihmisten ylilyönteinä ja katsottu, että kaltoin kohdelluksi tulleen pitäisi olla yhteydessä häntä hoitaneeseen henkilöön ja sopia asiat tämän kanssa henkilökohtaisesti. Tämä siitäkin huolimatta, että useat niin hoidetuista kuin hoitajista ovat jo kuolleita, mutta haavoitettuja saattavatkin olla hoidettujen perilliset, hoitokokouksissa läsnä olleet 
lapset tai muut hoidettavien läheiset. Linjakumpu kritisoi vahvasti liikkeen johtohenkilöiden kommentteja hoitokokouksista. Liikkeen lisäksi Linjakumpu heittää pallon myös kirkolle ja valtiolle: miten hengellinen väkivalta on hyväksyttävissä?

Uuden vuosituhannen alussa internet ja myöhemmin sosiaalinen media tarjosivat tilan keskustella hoitokokouskokemuksista. Linjakumpu peräänkuuluttaa avointa keskustelua liikkeen sisällä; jäsenten tulisi saada ilmaista mielipiteensä ilman, että heitä syytetään väärästä hengestä tai eriseuraisuudesta. Lukuisilla, erityisesti nuoremman polven vanhoillislestadiolaisilla, on aito halu kehittää liikettään, hengellistä kotiaan eteenpäin. Linjakumpu kohdistaa syyttävän sormensa liikkeen johtoon, joka on pyrkinyt peittelemään epäkohtia, psykologisoimaan ongelmia ja lakaisemaan niitä maton alle.

Itse jäin pohtimaan myös sukupuolen merkitystä, joka on hyväksikäyttö- ja naispappeuskysymyksissä noussut vahvasti esille. Miten sukupuoli näkyy hoitokokouksissa? Ymmärtääkseni hoitavat henkilöt olivat pääosin miehiä, sillä johtotehtävät liikkeessä kuuluvat edelleen miehille. Miten naisten ja miesten kokemukset hoidettavana olemisesta poikkesivat toisistaan? Minkälaisia seurauksia hoidettavana oleminen tai yhteisöstä erottaminen tuotti naisille ja miehille?

\section{KirjallisuUs}

ORWELL, GEORG 1999: Vuonna 1984. Helsinki: WSOY. [1949]

PYYSIÄINEN, ILKKA 2005: Synti. Ajatuksin, sanoin ja töin. Helsinki: WSOY.

RONIMUS, SEIJA 2011: Vartiossa maailmaa vastaan. Tutkimus Jehovan todistaja -yhteisöstä eronneiden kokemuksista. Turku: Turun yliopisto.

SUOLINNA, KIRSTI \& SINIKARA, KAISA 1986: Juhonkylä. Tutkimuspobjoissuomalaisesta lestadiolaiskylästä. Helsinki: SKS.

Filosofian tohtori, dosentti Tiina Mahlamäki on uskontotieteen yliopisto-opettaja Turun yliopiston historian, kulttuurin ja taiteiden tutkimuksen laitoksella. 